\title{
Comment
}

\section{An Open Letter to Congressman Gingrich*}

We urge you to reconsider your proposal to amend the House Rules to require a three-fifths vote for enactment of laws that increase income taxes.' This proposal violates the explicit intentions of the Framers. It is inconsistent with the Constitution's language and structure. It departs sharply from traditional congressional practice. It may generate constitutional litigation that will encourage Supreme Court intervention in an area best left to responsible congressional decision.

Unless the proposal is withdrawn now, it will serve as an unfortunate precedent for the proliferation of supermajority rules on a host of different subjects in the future. Over time, we will see the continuing erosion of our central constitutional commitments to majority rule and deliberative democracy.

\section{Original Intentions}

The present proposal is unprecedented, but it was anticipated by James Madison in a remarkably prescient discussion in The Federalist-a document

* Editor's Note: On December 7, 1994, Republican members of the House of Represcntalives proposed dramatic changes to the House Rules, including a measure that would require any tax increase to gain the votes of three-fifths rather than a majority of lawmakers. Leading consututional scholars submitted this letter to the future Speaker of the House. Newt Gingrich (R-Ga.). on December 23. 1994 When the 104th Congress convened on January 4, 1995, the Rules Committec, chaired by Gerald B.H. Solomon (R-N.Y.) limited debate on the measure to 20 minutes. The measure passed by a vote of 279 to 152. On February 8, 1995, 15 Members of the House. joined by the League of Women Voters and individual constituents, filed suit in federal district cour challenging the constitutionality of the new Rule.

1. Limitations on Tax Increases: (a) No bill, joint resolution, amendment or conference report carrying an income tax rate increase could be considered as passed or agreed to unless so determined by a vote of at least three-fifths of the House. (b) No measure or amendment could be considered that contains a retroactive income tax rate increase.

H.R. Res. 6, 104th Cong., 1st Sess. $\$ 106$ (1995). 
that you rightly urge your colleagues to reread with care. The Federalist No. 58 explicitly addresses complaints concerning the constitutional design of the House. It concludes by confronting an objection "against the number made competent for legislative business." Madison's description perfectly fits the present proposal: "It has been said that more than a majority ought to have been required for a quorum; and in particular cases, if not in all, more than a majority of a quorum for a decision." ${ }^{.2}$ Madison rejects this suggestion, but only after recognizing that it serves certain values-notably it might serve as a "shield to some particular interests, and another obstacle generally to hasty and partial measures." 3 Nonetheless, he finds these considerations "outweighed" by more fundamental ones:

In all cases where justice or the general good might require new laws to be passed, or active measures to be pursued, the fundamental principle of free government would be reversed. It would be no longer the majority that would rule; the power would be transferred to the minority. Were the defensive privilege limited to particular cases, an interested minority might take advantage of it to screen themselves from equitable sacrifices to the general weal, or in particular emergencies to extort unreasonable indulgences. ${ }^{4}$

Madison's audience understood the backdrop of these remarks. The Articles of Confederation required congressional supermajorities for especially important subjects, including the raising and spending of money. ${ }^{5}$ But the Philadelphia Convention decisively rejected such a system, repeatedly voting down key proposals that would have imposed supermajorities in legislative fields of special sensitivity. ${ }^{6}$ In The Federalist No. 22, Alexander Hamilton explicitly defended this decision to break with the supermajority system of the Articles, insisting that ordinary legislation should not "give a minority a negative upon the majority."

The Founders' rejection of a selective supermajority rule for especially sensitive legislation was neither casual nor peripheral to their larger design. Instead, it was based on practical experience and careful consideration of the arguments on both sides. Nothing in the past two centuries of our history

2. THE FEDERALIST No. 58, at 396 (James Madison) (Jacob E. Cooke ed., 1961) (emphasis added).

3. Id. at 396-97.

4. Id. at 397.

5. ARTS. OF CONFED. art. IX, $\$ 6$ (1781).

6. These proposals sought to impose a two-thirds rule on legislation dealing with commerce and navigation-fields that were understood to be sensitive precisely because they characteristically involved taxation. 5 Jonathan Elliot, Debates on the Adoption OF THE FEderal CONSTTTUTION 489-92, 552 (reprint ed. 1987) (1888).

7. THE FEDERALIST No. 22, at 140 (Alexander Hamilton) (Jacob E. Cooke ed., 1961). Like Madison, Hamilton counseled that "much ill may be produced, by the power of hindering the doing what may bo necessary, and of keeping affairs in the same unfavorable posture in which they may happen to stand at particular periods." Id. at 141 . 
authorizes a simple majority of the House to take unilateral action and restrike the constitutional balance.

\section{Constitutional Text and Structure}

Of course, there are times when the Constitution weighs the balance differently. On seven different occasions, it stipulates a supermajority requirement. ${ }^{8}$ But it never makes three-fifths, rather than two-thirds, the numerical hurdle. More fundamentally, it never places any special obstacles in the way of the enactment of ordinary legislation signed by the President.' As the Chadha case teaches, this carefully considered lawmaking system can only be changed by constitutional amendment. ${ }^{10}$

If the present proposal were legitimate, it would set a precedent for endless proliferation of supermajority requirements. If income tax increases can be subject to a special rule, why not national defense or civil rights? Since a $60 \%$ rule has no special place in the constitutional text, why not $55 \%$ or $73 \%$ ? Indeed, the present proposal already suggests how easily this logic may be extended. It not only contains a three-fifths rule for income tax increases, but imposes a kind of unanimity rule for the special category of "retroactive" taxes-already propelling us down the path of proliferation.

It is true that the Constitution gives each house the right "to determine the rules of its proceedings." This sensible housekeeping provision, however, does not authorize the House to violate fundamental principles of constitutional democracy. It simply authorizes the House to organize itself for informed and efficient debate and decision.

Indeed, we have no objection to supermajority rules so long as they fit comfortably within this rationale. Consider, for example, the House rule that requires a two-thirds vote to suspend the rules for the expeditious consideration of legislation. This supermajority requirement transparently serves the interest of efficient decision making. If it were too easy to suspend House rules, there would be undue disruption of the normal system of deliberation and decision; but if it were impossible, the House would be incapable of responding to

8. The original Constitution identifies five contexts for supermajonty rule-when ovemding

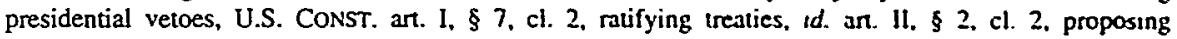
constitutional amendments, id. art. V, convicting on impeachments. id. art. I. $\$ 3$. cl 6, and expelling members, id. art. I. § 5, cl. 2, from the House or Senale. Two others are added by the Fourteenth Amendment (two-thirds of both Houses required to remove disability of rebellious officeholders) and the Twenty-Fifth Amendment (two-thirds of both Houses required to establish presidentual disability to discharge duties of office). In addition. the Twelfth Amendment requires an absolute majonty of the relevant chamber in cases where no candidate for President or Vice-President has won a majonty in the Electoral College.

9. The textual commitment to majority rule is also expressed by the grant of a vote to the VicePresident in those cases in which the Senators are "equally divided." U.S. CONST. ant. I, $\$ 3$.

10. INS v. Chadha, 462 U.S. 919 (1983).

11. U.S. CONST. art. I, § 5, cl. 2. 
emergencies. Hence, a two-thirds rule is a perfectly appropriate way to exercise the House's power "to determine the rules of its proceedings."

But the present proposal cannot be justified as a general procedure aimed at inducing deliberative decision making. It is simply based upon substantive and selective judgments that income tax increases-and only these increases-are unwise and should not be encouraged. Such opinions are entirely defensible, but they do not fall within the limited constitutional authority granted to each house over its "proceedings."

There is much more than language at stake. House rules are enacted on the first day of each session. Hence substantive judgments made in the rules cannot be the result of serious deliberation by the Members. House rules are made unilaterally without consultation with the Senate. Hence substantive judgments cannot be reached after the complex bicameral process contemplated by Article I. House rules are made by a bare majority. Hence the enactment of supermajority rules provides a mechanism to transform a narrow majority into a supermajority at a time when the process of substantive deliberation has not yet seriously begun. The introduction of substantive policies into procedural rules, then, undermines the system of deliberative democracy established at the Founding.

Defenders of the supermajority rule have minimized its threat to constitutional values by suggesting "that the same House majority that votes to impose a three-fifths rule could as easily vote to rescind that rule if it truly wanted to raise taxes."12 But this claim is simply false. Once the $60 \%$ provision is on the books, its operation would apply to tax legislation unless the House agreed to suspend its rules. Such a suspension, however, can only occur after a two-thirds vote. House traditions even give the Speaker unilateral authority to refuse to recognize a motion to suspend the rules, even if twothirds of the Members wish to allow the majority to have its say. ${ }^{13}$

Indeed, even if the House wished to reconsider an opening-day decision to impose a three-fifths rule, it would have great difficulty doing so. Such an effort normally requires the prior approval of the House Rules Committee, whose composition does not mirror the House as a whole. The only remaining method for reconsideration is the notoriously difficult procedure by which 218 Members may force the Rules Committee to "discharge" a measure that it has bottled up. ${ }^{14}$ While 218 is an absolute majority of the whole House, requiring such a large number is inconsistent with Madison's insistence that "a majority of a quorum" should suffice for ordinary legislation. By the time this mechanism could be employed, moreover, the chance to vote on pending tax measures may have long since passed.

12. Roger Pilon, Letter to the Editor, N.Y. TIMES, Dec. 16, 1994, at A38.

13. See Charles Tiefer, Congressional Practice AND Procedure 299 (1989).

14. Id. at 314-26. 
There is no escape, then, from the conclusion that the proposed rule strikes at the heart of the system of deliberative democracy established by the Constitution.

\section{Congressional Practice}

The $60 \%$ proposal seems to be based on an analogy to the Senate's practice on cloture. Whatever the constitutional merits of the filibuster rule, it does not provide a sound precedent. By making it hard to stop filibusters, the cloture rule encourages more fully informed discussion and thus falls within the rationale of the Constitution's grant of rulemaking power to both houses. In contrast to this general procedural norm, the House proposal is selective and substantive. It is simply beyond the scope of the House's rulemaking authority.

It is quite true that, since 1985 , Congress has passed new rules requiring a three-fifths majority in the Senate as part of the budget reconciliation process. ${ }^{15}$ While these provisions are vulnerable to our constitutional objection, they are such recent innovations that they can hardly count as a "tradition" that demands constitutional respect.

\section{Supreme Court Review}

We believe that the constitutional violation created by the proposal is sufficiently plain and fundamental to warrant action by the Supreme Court. As the Court cautioned in United States v. Ballin, House rules may not "ignore constitutional restraints or violate fundamental rights."16 The Court went on to elaborate principles of constitutional interpretation of decisive significance in the present case:

[T] he general rule of all parliamentary bodies is that, when a quorum is present, the act of a majority of the quorum is the act of the body. This has been the rule for all time, except so far as in any given case the terms of the organic act under which the body is assembled have prescribed specific limitations. ${ }^{17}$

We emphasize, however, that it would be far better to rethink the issue at this stage than to invite litigation. Not only would litigation lead to a protracted period of uncertainty, it would also destroy a valuable, two-century-

15. Kate Stith, Rewriting the Fiscal Consurution: The Case of Gramm-Rudman-Hollings. $76 \mathrm{CAL}$ L. REV. 593, 666 (1988). These rules were expanded in scope in the Omnibus Budget Reconctiation Act of 1990, Pub. L. No. 101-508, $\$ 13208,104$ Stat. 1388, 1388-619. As in previous years. Congress made it clear that such statutory creation of supermajority rules involved "an exercise of the rulemaking power of the ... Senate." Id. \& 13305, 104 Stat. at 1388-627: see also Pub. L. No. 103-66. \$ 1\$004. 107 Stat. 685 (1993) (reaffirming rulemaking powers of Senate and House).

16. United States v. Ballin, 144 U.S. 1. 5 (1892).

17. Id at 6 . 
old House tradition of constitutional self-restraint in the exercise of its rulemaking powers. It would be far better to redeem this tradition now without the need of an unnecessary confrontation with the Court.

Indeed, both the Senate and the President would also find themselves drawn into the controversy. Both would be required to define their own constitutional responsibilities if a tax measure gained the support of a House majority that fell short of three-fifths. The resulting confusion would undermine fundamental commitments to the rule of law and would predictably draw the Supreme Court into the affair.

Under applicable precedent, Representatives have standing to challenge basic lawmaking practices that dilute the voting power the Constitution grants to them and their constituents. ${ }^{18}$ Other cases establish that the Supreme Court will intervene on the merits to protect the integrity of the deliberative and democratic process established by the Constitution. ${ }^{19}$

But the better part of wisdom is to avoid confrontation and return to the foundations of deliberative democracy laid down by Madison in The Federalist.

$\begin{array}{ll}\text { Bruce Ackerman } & \text { Professor of Law and Political Science, Yale University } \\ \text { Akhil Amar } & \text { Professor of Law, Yale Law School } \\ \text { Jack Balkin } & \text { Professor of Law, Yale Law School } \\ \text { Susan Low Bloch } & \text { Professor of Law, Georgetown University Law Center } \\ \text { Philip Bobbitt } & \text { Professor of Law, University of Texas Law School } \\ \text { Richard Fallon } & \text { Professor of Law, Harvard Law School } \\ \text { Paul Kahn } & \text { Professor of Law, Yale Law School } \\ \text { Philip Kurland } & \text { Professor of Law, University of Chicago Law School } \\ \text { Douglas Laycock } & \text { Professor of Law, University of Texas Law School } \\ \text { Sanford Levinson } & \text { Professor of Law, University of Texas Law School } \\ \text { Frank Michelman } & \text { Professor of Law, Harvard Law School } \\ \text { Michael Perry } & \text { Professor of Law, Northwestern University School of Law } \\ \text { Robert Post } & \text { Professor of Law, University of Cal. School of Law (Boalt Hall) } \\ \text { Jed Rubenfeld } & \text { Professor of Law, Yale Law School } \\ \text { David Strauss } & \text { Professor of Law, University of Chicago Law School } \\ \text { Cass Sunstein } & \text { Professor of Law, University of Chicago Law School } \\ \text { Harry Wellington } & \text { Dean, New York Law School }\end{array}$

Note: Institutional affiliations are for purposes of identification only.

18. Michel v. Anderson, 14 F.3d 623, 625 (D.C. Cir. 1994); see also Kennedy v. Sampson, 511 F.2d 430, 433 (D.C. Cir. 1974) (holding that Senator had standing to challenge pocket veto that allegedly nullified his vote); Bames v. Kline, 759 F.2d 21, 25-30 (D.C. Cir. 1985), vacated as moot sub nom. Burke v. Barnes, 479 U.S. 361 (1987) (reaffirming Kennedy analysis of standing); PAUL M. BATOR ET AL., HAKT AND WECHSLER'S THE FEDERAL COURTS AND THE FEDERAL SYSTEM 157 n.7 (3d ed. 1988); LAURENCE H. TRIBE, AMERICAN CONSTITUTIONAL LAW 152-54 (2d ed. 1988).

19. See INS v. Chadha, 462 U.S. 919 (1983); Powell v. McCormack, 395 U.S. 486 (1969). 